University of Nebraska - Lincoln

DigitalCommons@University of Nebraska - Lincoln

Faculty Papers and Publications in Animal

Science

Animal Science Department

2000

\title{
Designing and Conducting Experiments for Range Beef Cows
}

Don C. Adams

University of Nebraska-Lincoln, dadams1@unl.edu

Merlyn K. Nielsen

University of Nebraska-Lincoln, mnielsen1@unl.edu

Walter H. Schacht

University of Nebraska-Lincoln, wschacht1@unl.edu

Richard T. Clark

University of Nebraska-Lincoln

Follow this and additional works at: https://digitalcommons.unl.edu/animalscifacpub

Part of the Animal Sciences Commons

Adams, Don C.; Nielsen, Merlyn K.; Schacht, Walter H.; and Clark, Richard T., "Designing and Conducting Experiments for Range Beef Cows" (2000). Faculty Papers and Publications in Animal Science. 510. https://digitalcommons.unl.edu/animalscifacpub/510

This Article is brought to you for free and open access by the Animal Science Department at DigitalCommons@University of Nebraska - Lincoln. It has been accepted for inclusion in Faculty Papers and Publications in Animal Science by an authorized administrator of DigitalCommons@University of Nebraska - Lincoln. 


\title{
Designing and conducting experiments for range beef cows ${ }^{1}$
}

\author{
D. C. Adams ${ }^{\dagger}, *, 2$, M. K. Nielsen ${ }^{\dagger}$, W. H. Schacht ${ }^{\dagger}$, and R. T. Clark ${ }^{\dagger} *$ \\ ${ }^{\dagger}$ Departments of Animal Science, Agronomy, and Agricultural Economics, University of Nebraska, Lincoln 68583 \\ and *West Central Research and Extension Center, North Platte, NE 69101
}

\begin{abstract}
Designing and conducting effective research for range beef systems involves analysis of intended application of the results, identification of factors affecting variation, and selection of appropriate research methods so that precise inferences can be made. Variances associated with time, location, animal, and error in grazing research can be high. Variation due to treatment $x$ location and treatment $\times$ time interactions is reduced by increasing the number of locations and periods tested. Random error is reduced by increasing the total number of observations. Animals, pastures, and weather are significant sources of variation in grazing studies. Factors that influence nutrient requirements or nutrient intake of cows are potential sources of variation. Amount and quality of herbage produced are highly variable within and among years and are closely related to the amount and pattern of precipitation. Vegetative measurements (e.g., cover or standing biomass) should be planned as a step in developing experimental designs and to aid in experimental layout and interpretation of the data. Vegetation sampling should be less intensive and largely descriptive in large study areas when the objectives are to measure a livestock production response and vegetation responses are considered incidental. As the priority of the objectives moves toward emphasizing plant response and the size of the study area declines, the intensity of sampling on a land unit basis increases and the need for precision increases. Generally, multiple years of study are required to address between-year variances. Experimental units and replication are key to effective experimentation. Without replication in space and(or) time, there would be no estimate of experimental error. In supplementation studies on range, experimental units are generally animals, pastures, or ranches. Animal, pasture, and ranch have advantages and disadvantages as experimental units. The advantages and disadvantages are related to hypothesis, objectives, inference, resources, number of animals, and number of treatments. When economic evaluations are part of systems research, economists should be involved in planning the experiment and formulating hypotheses. Hypotheses and interpretation of biological data may be different than for economic data. Costs need to be estimated for correct unit of output, and cost alone may be insufficient to properly rank the economic outcomes of the research.
\end{abstract}

\section{Key Words: Experimental Design, Range Management, Beef Cattle, Grazing}

\section{Introduction}

Research on rangelands is challenging. Large year-toyear and(or) season-to-season differences occur in the quality (Streeter et al., 1968; Adams and Short, 1987) and quantity (Kartchner et al., 1983; Smoliak, 1986) of forage produced. Physical features of the landscape affect herbage utilization (Holscher and Woolfolk, 1953; Cook, 1966). Breed and physiological status of the cow affect behavior (Herbel and Nelson, 1966; Stricklin et al., 1976) and nutrient requirements (NRC, 1996). Weather affects herbage production (Smoliak, 1986), animal behavior (Adams et al., 1986; Pfister et al., 1998), and animal requirements (NRC, 1996). Interaction among landscape, weather, breed, and physiological status of the cow results in highly variable effects on grazing research. Variances associated with time, location, animal, and experimental error in grazing research can be large.

Methods have been described to manage natural variation so that it contributes little to differences among treatment means (Cochran and Cox, 1957; Steel and Torrie, 1980). Less has been published specifically addressing experimental units, replicating treatments, and considerations for reducing error in research with range livestock. Because of the complexity of range landscape, weather, animal variables, and economics, a need exists to study production systems. Systems can be difficult and costly to replicate in space, and methods to reduce experimental error may limit inferences. Our objectives were 1) to identify and discuss strategies for dealing with sources of variation, reducing experimental error, selecting experimental units, and using replication in grazing animal research and 2) to provide insight on designing and conducting grazing research that can be applied to production systems.

\section{Sources of Variation}

A summary of potential sources of variation from cattle and rangeland in grazing experiments is given in Table 1.

\section{Breed of Cow}

Several factors related to grazing conditions interact with genetic variation; therefore, it is essential that the breed or combination of breeds selected for observation represents the population to which inferences are to be made. With highly variable nutrient content of range forages within and among years and extended period(s) of low forage quality (Streeter et al., 1968; Adams and Short, 1987), response to grazing treatments will be affected by factors that increase nutrient 
requirements. Increasing levels of milk production increases nutrient requirements (NRC, 1996). Adams et al. (1993) reported marked difference in change in body condition score between breeds of cows with high and low milk production during late summer grazing on range. Grazing and walking increase energy expenditure of cattle (Osuji, 1974). Differences in grazing time (Herbel and Nelson, 1966; Stricklin et al., 1976) and distance traveled (Herbel and Nelson, 1966; Anderson and Urquhart, 1986; Lathrop et al., 1988) occur among different breeds of cattle. Winder et al. (1996) found that genetic composition of the cow affected utilization of key plant species on Chihuahuan desert ranges.

\section{Body Size and Body Condition}

Differences in body size and body condition within a crossbred cow herd affected grazing activity, forage intake, and body weight gains during winter grazing (Adams et al., 1987). Body condition also can affect interpretation of data. Adams et al. (1987) fed cows in drylot to be either fat or thin during summer. During subsequent winter grazing, differences in forage intake were found when intake was expressed as kilograms of forage $/ 100 \mathrm{~kg}$ of body weight. However, no differences in forage intake were observed when intake was expressed on a body weight basis when cows were in similar body condition before the summer feeding period.

\section{Cow Age and Production Status}

Nutrient requirements of the cow increase with advancing gestation. Age of the cow and days into lactation after calving affect milk production and, thus, nutrient requirements (NRC, 1996). Birth date or age of calf and sex of calf affect weaning weight of the calf (Adams et al., 1989; Adams et al., 1993). Amount of milk produced affects calf weaning weight and body condition score of the cow (Adams et al., 1993; Short et al., 1996; Lamb et al., 1997).

\section{Origin and Experience of the Animal}

Butts et al. (1971) transferred Hereford cows originating in Montana or Florida to the opposite location. After the transfer, $50 \%$ of the cow herd at each location was from the original location and $50 \%$ was from the transfer location. During the first $7 \mathrm{yr}$ after the initial transfer, location $\times$ origin interactions occurred in both sexes of calf for birth, weaning, and yearling weights. Nutritional experience in early and adult life was shown to affect performance and dietary habits of sheep (Arnold and Maller, 1977). These observations indicate that mixing cattle of unknown or different origins, or with different nutritional experience, could be a significant source of variation if it is not accounted for in the allocation to treatments and(or) experimental analysis, regardless of the breed of the cow. Furthermore, Dwyer (1961) observed that even though cows tended to graze in groups, cows showed a great deal of individuality. Ganskop and Cruz (1999) concluded that researchers should not as- sume that naive cattle introduced to new forages provide an accurate depiction of the dietary composition of native stock. Naive cattle may sample a broader array of forages than their experienced counterparts and harvest fewer bites than from the preferred forages. Warren and Mysterud (1993) observed that sheep released into an unfamiliar herd on unfamiliar range strayed nearly $14 \mathrm{~km}$ from the herd's normal grazing area. Individual animal distribution within a pasture, diet selection, and other factors will likely result in variability in animal response to treatments.

\section{Pasture, Topography, and Water Location}

Differences in topography and physical attributes of the pasture can affect response of cattle to treatments by affecting energy expenditure for travel and grazing (Osuji, 1974). Steepness of slope and water location, vertical distance above water, and vegetation type affect cattle distribution and vegetation use in a pasture (Mueggler, 1965; Roath and Krueger, 1982). Cook (1966) tested the relationship between 21 variables (including percentage of slope, various vegetation traits, and water location) and use on mountain slope. Cook (1966) concluded that no one factor could be used as a reliable index to predict use and that no single measure of percentage of slope adequately evaluated the influence of slope on utilization of rough topography. Within a pasture, cattle prefer to graze specific range types and discriminate against rougher topography (Dwyer, 1961). In rougher terrain, cattle tend to follow the easiest topography (Dwyer, 1961). Selection of pastures with similar topography, size, and shape can reduce between-pasture variation, but the pasture should represent the topography and vegetation for which inferences are to be made.

Distance to water is probably the principal factor affecting livestock grazing distribution in pastures. Holscher and Woolfolk (1953) noted that total herbage utilization was nearly $100 \%$ within $100 \mathrm{~m}$ of water and declined to $20 \%$ within $200 \mathrm{~m}$ of water during summer-long grazing. Hart et al. (1991) observed that forage utilization was $60 \%$ near water, but it was less than $30 \%$ at distances greater than $5 \mathrm{~km}$ from water.

\section{Range Site and Condition}

Holscher and Woolfolk (1953) described range subtypes or sites characterized by different combinations of soil, topography, and composition of plant species. They observed that utilization of some species varied twofold between range sites.

Range condition and herbage allowance must be considered in using different pastures as replicates. High stocking rates reduce herbage basal cover, herbage production, and range condition (Houston and Woodward, 1966). Goebel and Cook (1960) observed that good-condition rangeland generally had a more desirable floral composition and higher production than low-condition rangeland. They also noted that a decrease in range condition was accompanied by a decline in length of leaves and stems and in flowering stalks. High 
stocking rate and(or) low range condition reduce weaning weight of calves (Houston and Woodward, 1966). Range condition affects forage intake, forage digestibility, and dietary crude protein or crude protein of the standing vegetation (Goebel and Cook, 1960; Cook et al., 1962; Powell et al., 1982). Low range condition generally is associated with lower nutritive and productive values. Stocking rates should be based on range condition and site. High stocking rate reduced diet quality, forage digestibility, forage intake, and body weight of lambs compared to a moderate stocking rate (Jung and Sahlu, 1989). The researcher must keep in mind that stocking rate is not based strictly on number of cows, but also includes body weight, gestation, lactation, and the nursing calf (Scarnecchia, 1985; Waller et al., 1986).

\section{Between-Year Differences in Nutrient Content of Forage}

Variances for year effects are often high relative to other sources of variation in grazing studies (Table 2). A major source of variation in grazing studies is year-to-year and(or) season-to-season fluctuations in nutrient content (Streeter et al., 1968; Adams and Short, 1987) and quantity (Streeter et al., 1968; Kartchner et al., 1983) of forage produced. During a 4-yr study, Kartchner et al. (1983) reported highly variable differences among years in grass, forb, and alfalfa production on range, contour-furrowed range interseeded with alfalfa, and contour-furrowed range interseeded with alfalfa and fertilized with ammonium phosphate. Total herbage production among the $4 \mathrm{yr}$ varied by $512 \mathrm{~kg} / \mathrm{ha}$ for untreated range and $2,682 \mathrm{~kg} / \mathrm{ha}$ for contour-furrowed range interseeded with alfalfa and fertilized. Potential effects of diet quality on nutrient intake and standing herbage on stocking rate are obvious.

One of the most effective methods to reduce the impact of high between-year variances is to extend the study over more years. The researcher must weigh the lower costs associated with a short-term study against the information and precision to be gained from adding years to a study. Variances for year and interactions with year may be high even with multiple-year observations. Grazing studies often must be conducted over multiple years to extend inferences to a broader array of environmental conditions and to test for year $\times$ treatment interactions. In some studies, years may be considered replications (Adams et al., 1989; Adams et al., 1994). More detail on this concept will follow.

\section{Weather}

A significant cause of between-year variance in grazing studies is weather. Recognizing impacts of weather on the animal and vegetation is essential in interpreting data, thus emphasizing the need to extend the study over multiple years, and in selecting pastures with similar physical attributes and topography for application of treatments or replication. The researcher also may adjust stocking rates to compensate for differences in herbage production resulting from variable precipitation. Common observations of betweenyear effects attributed to weather are precipitation and(or) drought (Hurtt, 1951; Judkins et al., 1985; Adams et al. 1989; Short et al., 1996) and harsh weather conditions (Kartchner, 1980). Precipitation is the most important single factor influencing herbage production (Holscher and Woolfolk, 1953; Stoddart et al., 1975; Smoliak, 1986). However, in semiarid regions, precipitation by itself is not the sole criterion affecting plant growth and yield (Kilcher, 1980; Smoliak, 1986). Both the pattern and amount of precipitation affect the amount of herbage produced (Smoliak, 1986; Hart, 1987) and nutrient content of cattle diets (Short et al., 1996). Forage production in Wyoming was highly correlated to total precipitation from March through May (Hart, 1987). Spring precipitation accounted for $94 \%$ of the annual variation in herbage production. On a southern Alberta range, precipitation from April through July was highly correlated with herbage production by August 1 each year (Smoliak, 1986). George et al. (1988) suggested that on California's winter annual rangelands, precipitation controls the beginning and end of the growing season, whereas temperature largely controls seasonal growth rates. Not all variation in forage production between years is a result of weather. For example, Kartchner et al. (1983) observed extensive use of standing forage by insects.

Cold ambient temperatures increase a cow's nutrient requirements (NRC, 1981, 1996) and may reduce forage intake ( Kartchner, 1980; Adams et al., 1986; Pfister et al., 1998), lower forage digestibility (Kartchner, 1980; Adams et al., 1986), and affect grazing behavior (Malachek and Smith, 1976; Adams et al., 1986, 1987; Pfister et al., 1998). Hot ambient temperatures have been observed to reduce grazing activity (Dwyer, 1961). Time spent grazing decreased with increasing wind speed during winter grazing (Adams et al., 1986). Wind also affects the orientation of cows and the direction they graze (Dwyer, 1961). It is accepted that topography of a pasture and vegetation can greatly influence the effects of wind. Pastures with topographic relief, trees, shrubs, or exposure away from prevailing winds would mitigate the effects of wind on cattle. Snow on the ground affects availability of forage for cattle to consume. Deep snow and snow with a crust of ice limit animal movement and grazing (Adams et al., unpublished). Pfister et al. (1998) observed that with increasing snow depth cows reduced daily grazing time and increased consumption of needles from ponderosa pine trees.

Because of potential animal genotype $\times$ environment interactions, it is critical that a genotype is selected for experimental material that will meet objectives and be appropriate to test the hypothesis. Care must also be given in designing the experiment so that valid genetic comparisons can be tested.

\section{Methods and Experimental Design Considerations}

\section{Approaching Research Problems}

A clear definition of intended application of the results of the research is essential in selecting experimental material and interpreting findings (SRM, 1986). There are two broad 
types of research with grazing beef cattle: 1) identification of fundamental mechanisms affecting plant and animal responses and 2) components of production systems. Experimental approaches and inferences for these two types of research can be very different. Researching fundamental mechanisms may be most effective when treatments are imposed on individual animals and efforts are made to reduce variation between animals, pastures (i.e., vegetation, topography, water), and weather. Traits studied in this type of research with grazing beef cattle are forage intake, passage rate of digesta, diet selection, animal behavior, and forage $x$ animal interactions. Inferences likely are to be specific to the treatments under study. In contrast to fundamental mechanisms, production systems research generally will be most effective when conducted on groups or herds of cattle in multiple pastures and years to allow broader inferences. Inferences may be intended for different vegetation types, varying weather conditions, or to varying genetic composition of cattle. Both types of research are needed and should complement each other. The intended objectives and inferences will affect the research material (i.e., rangeland and cattle) and resources to conduct the research. Available resources also should affect the research objectives and expected inferences. For example, if pasture and cattle resources are limited but ample laboratory and labor resources exist, the researcher might use resources most effectively to study fundamental mechanisms. If the researcher has access to large numbers of cattle and land resources but labor and laboratory are limiting, the researcher might most efficiently study components of production systems.

\section{Selection of Environment}

In some situations it may be important to have a broad environment for inferences. Pfister et al. (1997) conducted a series of grazing studies at nine locations in the mountains of Utah, Idaho, and Colorado to determine consumption of immature tall larkspur by cattle. Each location was considered an independent trial and animals were the experimental unit. The nine locations in three states provided inference for a large geographic area. The large inference was important because of the wide distribution of tall larkspur and the economic impact of its toxicity on cattle (Nielsen and Ralphs, 1988). Coombs et al. (1983) compared four pasture management systems for cow-calf production at two locations in Louisiana. They tested differences in the four systems within each location and made inferences to each location. We are currently collaborating with a private operation that has several Nebraska sandhill ranches with similar cow genetics and ranch management. We have administered supplement treatments at multiple ranches and consider ranch the experimental unit. Experimental error could be large because of differences between ranches in landscape, vegetation, precipitation, and management, but the inference is expanded over studies at one location. This collaboration was also a means to access a large number of animals not available at a university.

Proceedings of the American Society of Animal Science, 1999
Inferences are much different when biological mechanisms are studied. In such studies the inference may be intended for the animal or a forage $\times$ animal interaction. In these cases, spatial inference may be less critical.

\section{Selection of Statistical Models for Grazing Experiments}

Experimental error describes the failure of two identically treated experimental units to yield identical results. It includes errors of experimentation, errors of observation, errors of measurement, the variation among experimental units, and the combined effects of extraneous factors that influence the characteristics under investigation (Ostle and Mensing, 1975).

Grazing experiments with a completely balanced design can be described with the following general model:

$$
\mathrm{y}_{i j k m}=\mu+\mathrm{t}_{i}+\mathrm{l}_{j}+(\mathrm{t} 1)_{i j}+\mathrm{p}_{k}+(\mathrm{tp})_{i k}+\mathrm{e}_{i j k m},
$$

where $\mathrm{y}$ is the $\mathrm{m}^{\text {th }}$ observation in the $\mathrm{k}^{\text {th }}$ period of time in the $\mathrm{j}^{\text {th }}$ location and the $\mathrm{i}^{\text {th }}$ treatment. Terms for random error (e), the time period (p), and location (l) and the treatment $\times$ location and treatment $\times$ period interactions are assumed to be random. In grazing experiments, we want to measure the difference between two treatments so that we are as precise as possible when we predict which treatment will be better and by how much, when these treatments might be applied to any location in the area of inference and at any time in the area of inference. In other words, we want to make sure that observed differences in measurements are due to the treatments rather than to other effects. For the model we have described above with L locations, $\mathrm{P}$ time periods, and $\mathrm{n}$ observations within a treatment-location-period class, the variance of the difference in two treatment means is as follows:

$$
\begin{gathered}
\text { Variance (Treatment } 1-\text { Treatment } 2) \\
=2\left\{\left(\sigma_{\mathrm{TL}}^{2} / \mathrm{L}\right)+\left(\sigma_{\mathrm{TP}}^{2} / \mathrm{P}\right)+\left(\sigma_{\mathrm{E}}^{2} / \mathrm{LPn}\right)\right\} .
\end{gathered}
$$

Thus, the random variation due to the interactions of treatment with location and of treatment with time period are reduced by the number of locations and periods tested, respectively. Purely random error is reduced by increasing the total number of observations. Observations on impacts of additional pastures (i.e., locations), years (i.e., periods), and the total number of observations are demonstrated in the following two studies.

Downs (1997) studied the effects of grazing Nebraska Sandhills range in June or July at 33, 67, or $100 \%$ of seasonal stocking rates on subsequent diet quality of cows grazing the same site in November, January, and March during two winters. Each stocking rate imposed in June and July was applied to three 1-ha pastures with similar vegetation. Diets were collected from two esophageally fistulated cows in each pasture in November, January, and March. Mean squares and degrees of freedom from the analysis of variance for dietary crude protein and in vitro organic matter digestibility for year, pasture (treatment), year, treatment (year), and random error $\{$ e.g., year $\times$ pasture (treatment) $\}$ are

C 2000 American Society of Animal Science 
shown in Table 2. The error mean squares for year effects were large compared to pasture (treatment), treatment $\times$ year, and year $\times$ pasture (treatment). The SRM (1986) suggested that when animal response to grazing treatments is being measured, the trend over several years may be more important than the mean for only 1 or $2 \mathrm{yr}$. If this is the case, precision will increase each year because the number of observations increases over time.

Villalobos (1993) imposed four different supplement treatments on cows grazing winter range. Each treatment was fed to 12 gestating, spring-calving cows as a group in each of two pastures in each of $2 \mathrm{yr}$. Mean squares and df for pasture (treatment), treatment (year), and random error \{animal (pasture $\times$ year $\times$ treatment) $\}$ associated for change in cow body condition and body weight and on subsequent fall weaning weights are shown in Table 2. Mean squares for year and treatment $\times$ year were high for change in cow weight compared to pasture and animal (pasture $\times$ year $\times$ treatment). In contrast to change in cow weight, the mean squares for change in cow body condition score associated with year were low and similar to those for pasture and animal (pasture $\times$ year $\times$ treatment), indicating much less would have been gained by adding more years to the study compared to change in body weight.

When an experiment is conducted at one location and inference is to that location, but a pasture receives only one treatment, the following model fits:

$$
\mathrm{Y}_{\mathrm{ijk}}=\mu+\mathrm{t}_{\mathrm{i}}+\mathrm{p}_{\mathrm{ij}}+\mathrm{e}_{\mathrm{ijk}}
$$

where treatment (t) is fixed and pasture (p) and error (e) are random. With $\mathrm{P}$ pastures per treatment and $\mathrm{n}$ observations within a pasture, the variance of the difference between two treatment means is as follows:

$$
\begin{aligned}
& \text { Variance (Treatment } 1-\text { Treatment 2) } \\
& =2\left\{\left(\sigma_{\mathrm{p}}^{2} / \mathrm{P}\right)+\left(\sigma_{\mathrm{E}}^{2} / \mathrm{Pn}\right)\right\} .
\end{aligned}
$$

To minimize this expression, given limited resources, we need to minimize the following:

$$
\left(\mathrm{n} \sigma_{\mathrm{p}}^{2}+\sigma_{\mathrm{E}}^{2}\right) / \mathrm{Pn},
$$

and relative efficiencies of designs depend on the variances.

\section{Defining the Experimental Unit}

The experimental unit is the unit, plot, or animal to which a treatment is independently applied. The sampling unit may be the complete experimental unit or it may be some fraction of the experimental unit (Steel and Torrie, 1980). In range and pastureland research, the experimental unit is generally the animal or a group of animals within a pasture, but it could be extended to cattle on a farm or ranch treated the same. If the experimental unit appears more than once in an experiment, it is replicated. Repetitions in both space and time can be considered replication (Steel and Torrie, 1980). Without repetitions in space or time, there would be no estimate of experimental error and no way to know whether observed differences are real or are from inherent variation (Steel and Torrie, 1980).

\section{Experimental Units for Supplementation Experiments}

Some advantages and disadvantages of using animal, pasture, or ranch as the experimental unit in supplementation experiments are presented in Table 3 . If a group of cows in a common pasture are fed a supplement (treatment) as a group and each different supplement is fed to another group of cows in a different pasture, then a group of cows within a pasture is the experimental unit and the cow is the sampling unit. If each supplement is fed to cows in two or more pastures, pastures are the replicates (Cochran et al., 1986; Sanson et al., 1990; Villalobos et al., 1997a). If each supplement is fed only to cows in one pasture during one period of time, there would be no replication in time or space. It would not be known whether differences in cow response were due to the supplement or to variation in time, vegetation, diet selection, topography, exposure (i.e., north vs south) to the sun, water location, weather, or a myriad of other factors. A primary limitation to using pasture as the experimental unit may be the variability among pastures, and land resources may limit replications. When pastures are selected and developed with similar characteristics, the variation among pastures may be low (Table 2). As the land unit to support a cow increases, expected variability among experimental units increases (especially in complex plant communities).

Low degrees of freedom for pasture may make investigators question whether to use pasture as the experimental unit when conducting research as well as when completing the statistical analysis. This can be examined with a simple example of two treatments and $\mathrm{n}$ total animals, regardless of design, assigned per treatment. Degrees of freedom and the appropriate mean square for testing treatment differences are given below for varying numbers of pastures randomized for each treatment:

\begin{tabular}{lcc} 
Pastures/treatment (Trt) & $\begin{array}{c}\text { Error df for testing } \\
\text { Trt differences }\end{array}$ & $\begin{array}{c}\text { Mean square used for } \\
\text { testing Trt differences }\end{array}$ \\
\hline 1 & $2(\mathrm{n}-1)$ & Animal (Trt) \\
2 & $2(2-1)=2$ & Pasture (Trt) \\
3 & $2(3-1)=4$ & Pasture (Trt) \\
4 & $2(4-1)=6$ & Pasture (Trt) \\
5 & $2(4-1)=8$ & Pasture (Trt)
\end{tabular}

For example, if there is a total of 50 animals to receive each treatment and the design has only one pasture for a treatment, the error df for testing treatment differences is 98, whereas if one uses five pastures (10 animals per pasture) for each treatment, then the error df for testing treatment differences is eight. Using the examples above for all cases where $\sigma_{P}^{2}>0$, the power of the experiment (probability that the null hypothesis is rejected at the designated significance level when it is truly false; i.e., there are treatment differences) is greater than only using one pasture whenever the number of pastures is $\geq 3$. Power is larger but increases at a declining 
rate after three pastures. Only when $\sigma_{P}^{2}=0$ is the use of a single pasture the most efficient design.

If cows grazing in a common pasture are assigned to each supplement treatment and supplements are fed on an individual cow basis, then cow is the sampling unit, experimental unit, and replicate (Karn and Clanton, 1977; Kartchner, 1980; Marston et al., 1995). When cows are individually fed supplements within a pasture or when cattle receiving different treatments graze in a common pasture, variation between pastures is controlled. Supplementing cows on an individual basis will generally increase the number of replicates possible over group feeding. As the number of replicates increases, estimates of the treatment means become more precise (Steel and Torrie, 1980). Individual feeding is expected to reduce variation between animals because of more consistent consumption of supplement between cows. Individual feeding of supplements is particularly useful as the number of treatments increases, when a large number of pastures is not practical, and to reduce variation with varying pastures (Hollingsworth-Jenkins et al., 1996). Use of a common pasture for multiple treatments requires the assumption that there is not a treatment $\times$ pasture interaction. Results of individual feeding supplements are artificial to the extent that animals are handled much differently than they would be on a farm or ranch and competition between cows is removed. Rook (1999) concluded that designs in which cows are offered different supplement treatments and graze in the same pasture and cow is the experimental unit are unacceptable because of social facilitation, competition among animals, and feedback of defoliation on the sward.

Judkins et al. (1985) used one pasture for cows supplemented free choice with phosphorus and one pasture for control cows not receiving the phosphorus supplement. They periodically rotated cows from one pasture to the other to reduce the effects of such factors as forage availability and diet quality, and cow was assumed to be the experimental unit. Lardy (1997) fed nursing or weaned calves either a protein supplement or no supplement. To ensure that weaned calves did not suckle cows but had the same forage availability, weaned calves grazed in adjacent pasture to the calves nursing cows. Each day weaned calves and nursing calves grazed a different one of two pastures to minimize pasture effects and calf was the experimental unit. Villalobos et al. (1997a) and Hollingsworth-Jenkins et al. (1996) used a combination of pasture and animal as the experimental units in experiments with protein supplements during winter grazing. Four protein supplement treatments were replicated in eight pastures with 12 cows/pasture and pasture was the experimental unit. Cow performance traits were tested with pasture as the experimental unit. A subset of cows from each pasture was combined in a common adjacent pasture (with similar forage and topography) for 10 to $12 \mathrm{~d}$ to measure forage intake. While intake was being measured, supplements were fed on an individual cow basis, and cow was the experimental unit. Combining a subset of cows in a common pasture eliminated the between-pasture variability, increased the number of replicates, and reduced equipment and labor needs. This approach also limited the number of esophageally fistulated cows needed for diet collection and steers needed for total fecal collections to determine recovery of the fecal marker. Karn (1997) grazed cows on a control and phosphorous-supplement treatment in a common pasture, gathered the cows, and fed the supplement to cows in treatment groups.

\section{Experimental Units When Treatments Are Applied to Animals}

Use of the cow or calf as the experimental unit is common when treatments are breed (Winder et al., 1996), sire traits (Colburn et al., 1997), body size, body condition (Adams et al., 1987), cow age (Adams et al., 1986), physiological status (i.e., pregnant vs not pregnant; Anderson and Urquhart, 1986), or milk production (Lathrop et al., 1988; Adams et al., 1993). When treatments such as growthpromoting implants are applied at one or several points in time (Hancock et al., 1994), rather than daily or at frequent intervals, such as in the case of feeding supplements, use of the cow as the experimental unit is also common.

\section{Experimental Units When Testing Forage $\times$ Animal Interactions}

In experiments in which treatments such as breed of cow or weaning are imposed in combination with a forage treatment, a split-plot design might be used. The split-plot would result in different experimental units to test forage and animal treatments imposed simultaneously. For example, forage treatment(s) could be in the main plot with pasture as the replicate and the animal treatment in the subplot with cows as the replicate (Adams et al., 1993; Lamb et al., 1997).

The choice of designing an experiment in which cow is the experimental unit vs a group of cows within a pasture as the experimental unit may vary with resources and experimental objectives. Our experience indicates that individually feeding a supplement, compared to group feeding, generally increases labor requirements and equipment to sort and feed animals. If the objective is to test the response to two or more supplements under ranch or farm conditions or as part of a ranch system, group feeding the supplement to cows seems most appropriate. In many grazing studies, the choice of experimental unit may be affected more by resources to conduct the research than by "ideal" design to reduce error or control variation. Most researchers have limited land, animal, and labor resources to conduct an experiment. A challenge in grazing animal research is how to approach research in such a way that given resources can support and yet test appropriate and meaningful hypotheses.

\section{Commingling Cattle of Different Biological Type or on Different Treatments}

Commingling is common in grazing studies with cattle. In studies in which cows receiving different treatments graze a common pasture, effects of one treatment might modify the 
response of another treatment. Ralphs (1997) conditioned cattle to avoid tall larkspur (Delphinium occidentale [S. Wats.] S. Wats.); however, cattle lost their aversion to tall larkspur and consumed the plant when grazing with nonaverted cattle. Oldenbrock and Jansen (1978/79) reported small differences in performance when different breeds of cattle were commingled compared to the same breeds that were not commingled. Wagnon (1963) observed that range cattle supplemented with protein had different feeding and activity patterns than unsupplemented cows. Although the possibility exists, we are not aware of any data showing that unsupplemented cows commingled with supplemented cows would or would not affect performance of either group. To facilitate supplementing individual cows, all cows are gathered, moved to corrals, sorted, and penned. On a farm or ranch, the cattle would likely move to a feeding area on their own within sight of the person delivering the supplement or by sound of a horn or siren without being handled. If one treatment in a study is unsupplemented, unsupplemented cows are also gathered, unlike in a ranch situation.

\section{Reducing Experimental Error}

Earlier we demonstrated that increasing the number of pastures, time periods tested, and observations reduces pasture, time, and experimental error variance contributions to the variance of treatment comparisons. Experimental error also can be reduced by selection of animals and pastures to reduce variability between experimental units. The researcher must select representative pastures and animals so that inferences can be made for a much larger population (SRM, 1986). The following sections present a number of considerations for selecting animals and pastures to reduce error and be representative of the population for inference.

\section{Vegetation Sampling}

Treatments and measurements can be identified and described after the objectives and hypotheses of a proposed range livestock study have been clearly stated. Minimal vegetation sampling is necessary during the conduct of a study if the experimental unit is animal and the objective of the study is to determine animal response to treatments, such as in breed comparison or supplemental feeding studies. When animal is the experimental unit, pasture variability and pasture $\times$ treatment interactions are assumed to be inconsequential to the objective(s) of the study. Studies with objectives emphasizing plant/animal interactions (e.g., diet or grazing pressure studies), when pasture is the experimental unit, typically require a major commitment to collection of appropriate vegetation data.

\section{Preliminary Vegetation Sampling}

Regardless of the objectives, before a study is designed an accurate description of the experimental material and conditions under which the treatments will be compared is needed (SRM, 1986). In most cases, vegetation measure- ments must be made to characterize the temporal and spatial distribution of vegetation parameters (e.g., cover or standing crop biomass) as a step in developing appropriate experimental design and assisting in the layout of the study. Appropriate vegetation sampling and subsequent design considerations minimize experimental error.

Appropriate methods of vegetation sampling for characterization of the study area depend on a number of factors, including study area size, vegetation data available from previous sampling efforts, labor and equipment resources, objectives of the study, and vegetation measurements to be taken during the conduct of the study. Vegetation sampling should be less intensive and largely descriptive in large study areas when the objectives are to measure livestock production response to such management factors as supplemental feeding or breeds and vegetation effects and(or) responses are considered incidental. The minimum vegetation-related information needed for the layout of the study site and spatial inference would be a detailed map of vegetation cover, as provided by range site and range condition surveys or habitat-type mapping. Detailed range site and condition surveys are periodically conducted by federal land management agencies and habitat types can be classified by aerial photographs or on the ground by trained personnel. As the priority of the objectives moves toward emphasizing plant response and the size of the study area declines, the intensity of sampling on a land unit basis increases and the need for precise estimates increases.

\section{Studies Emphasizing Animal Response Objectives}

In range livestock studies, vegetation parameters often are assumed to be inconsequential when the priority is quantifying animal response and animal is the experimental unit. Even under these circumstances, however, sampling relevant vegetation parameters should be considered. Animal response (e.g., performance) will likely change between seasons and years and explanations for these fluctuations may be based largely on the forage resource; therefore, interpretation of results of these grazing studies should be based on animal response measurements in combination with vegetation measurements (Downs, 1997). To characterize the forage resource, estimates of standing crop biomass are most commonly recommended, especially in studies extended over several years, to assist in explaining variability in animal performance among years. Total amount of herbage available, however, cannot be related to animal performance in situations other than when there is a forage deficiency. With further sampling intensity, other more relevant parameters can be derived, such as proportions of species or forage types, live plant yields, or forage quality, which are meaningful in explaining variability in animal performance.

\section{Studies of Plant-Animal Interactions}

More intensive vegetation sampling is required when 1) a vegetation measurement alone (e.g., herbage availability) or in combination with a land- or animal-related factor (e.g.,

C 2000 American Society of Animal Science 
grazing pressure) is a treatment or 2) a vegetation measurement is a response variable used to quantify the effect of grazing or a grazing management treatment on herbage characteristics. The experimental unit for studies dealing with plant response is pasture. Sample location within a pasture cannot be an experimental unit because grazing-related treatments are generally applied to the pasture as a whole and locations within a pasture are not independent (Cox, 1958; Brown and Waller, 1986). Research at the plantanimal interface typically requires homogeneous experimental material and relatively small plots/paddocks are needed to achieve the level of precision required to detect treatment differences (Hodgsen et al., 1994). To establish plant-animal interactions, sampling intensity must be high and efficiency of sampling must be a principal concern.

\section{Sampling Efficiency}

Because of the inherent variability on rangelands, arriving at acceptable levels of precision when sampling vegetation is problematic. Sampling variation is due to macro- and microheterogeneity of the site, observer and equipment errors of measurement, and logistic problems or inadequate availability of resources (Morley, 1982). Sampling error can be minimized by such practices as systematic stratification of the sampling area, appropriate sampling methods, and observer training; however, standard errors normally will still be relatively high and the associated number of samples needed to arrive at acceptable levels of statistical significance will be very high. Before designing the sampling procedure, the researcher should estimate the minimum level of precision needed to detect treatment differences that are biologically significant. Vegetation data collected on similar sites in the past should be used to calculate the natural variability among replications and among sample units within replications. These statistics can be used to estimate replication/sample numbers needed to achieve an acceptable level of precision (Steel and Torrie, 1980; McIntyre, 1982).

The most meaningful vegetation parameters to be measured at the plant-animal interface are standing crop biomass and its components (e.g., percentage leaf or relative species composition). The most suitable methods of estimating biomass and related variables depend on the type of vegetation, size of area to be sampled, topography, acceptable levels of precision, and labor and equipment resources. Destructive harvest of vegetation within quadrats is the conventional method of estimating biomass, but it requires considerable time and labor resources (Frame, 1981; SRM, 1986). Various indirect, nondestructive, and(or) mechanized methods of sampling standing crop biomass have been developed and should be used to improve sampling efficiency when appropriate. Many indirect methods of estimating standing crop biomass, such as the drop-disc meter (Sharrow, 1984; Rayburn and Rayburn, 1998), the canopy analyzer (Welles and Norman, 1991; Volesky et al., 1999), visual obstruction measurements (Robel et al., 1970; Volesky et al., 1999), and radiometric reflectance measurements (Anderson and Hanson, 1992), yield acceptable estimates of total biomass but do not allow for differentiation by plant species or other components of the total. Other indirect methods, such as the dryweight-rank method ('t Mannetje and Haydock, 1963; Catchpole and Wheeler, 1992) and double-sampling methods (Anderson and Kothmann, 1982; Ahmed et al., 1983), are designed to estimate biomass of individual species. Estimating yields of other components of the standing crop biomass is problematic and relatively few indirect methods are available; however, advances have been made in estimating leaf:stem ratios (Smart et al., 1998) and live:dead tissue ratios (Gillen and Tate, 1993) using indirect methods. In most cases, the time required for sampling becomes a critical consideration and investigators should explore alternative experimental designs or sampling methods so that the objectives are not compromised.

Decisions about vegetation sampling intervals are important and influence resource use efficiency. In general, sampling should be conducted only when the quantity or quality of vegetation would be expected to affect animal performance. Making vegetation measurements at specified intervals without particular regard to animal needs or performance may represent inefficient use of resources. In addition, researchers and their sampling methodology should allow for the flexibility needed to respond to unexpected changes in animal performance with an efficient means of readily making relevant herbage measurements (Morley, 1982).

\section{Remote Sensing}

Remote sensing commonly is recommended as a tool to arrive at estimates of vegetation cover, standing crop biomass, or other biophysical variables. Estimating the amount of vegetation by multispectral, remotely sensed means is usually impractical for diverse rangeland situations because of a variety of environmental and sensor effects. Only when these effects are understood at the scale of the leaf, canopy, and field can there be accurate remote sensing of vegetation amount on rangeland (Huete and Jackson, 1987; PerezCastillo, 1998). More conventional means of estimating vegetation parameters are still the recommended methods.

\section{Forage Utilization}

Most studies designed to quantify plant-animal relationships are enhanced greatly by estimates of utilization (i.e., herbage disappearance). Achieving precise estimates of plant growth or utilization is particularly demanding because of the large number of samples required. Reducing sample intensity because of a shortage of labor and equipment resources only confounds the situation and results in useless data. Estimates of utilization based on variables other than disappearance of herbage biomass are used commonly because they allow for high levels of precision with relatively low inputs of time and labor. Percentage grazed tillers and height of grazed tiller are plant characteristics commonly measured to arrive at indices of utilization (Gillen et al., 1990; Derner et al., 1994). These indices of utilization can be converted to estimates of utilization by collecting appropriate 
plant data that establish the relationship between percentage of grazed tillers and(or) height of grazed tillers and utilization (Cullan et al., 1999).

\section{Canopy Structure}

Establishing the relationship between animal performance, behavior, or intake and available herbage requires more than estimates of standing crop biomass, species composition, or forage quality. Canopy structure of the vegetation cover interacts with species composition and plant maturity in affecting diet selection of grazing animals. For studies designed to establish and model the plant-animal interface for a particular plant community type, measurements are required of such canopy characteristics as percentage leaf, leaf length and density, tiller height, and plant size (Mitchell et al., 1991; Laca et al., 1992; Brummer, 1994). Research related to the effect of canopy structure on diet selection has focused on monocultures or simple mixtures of forage plants where spatial and temporal variability in canopy characteristics is relatively small. Achieving precise estimates of canopy structure parameters for rangeland plant communities is unrealistic in most experimental settings.

\section{Indirect Methods}

Diet composition of grazed forages, botanical composition, amount of forage consumed, and digestibility are determined by various indirect methods. Forage intake and digestibility estimates may involve several different animals to arrive at an estimate for one animal. For example, different sets of animals are needed to collect diet samples, for marker recovery, to calibrate total fecal output, and to provide rumen inoculum for in vitro digestibility analysis (Tilley and Terry, 1963; Kartchner, 1980; Villalobos et al., 1997a). Each part of the procedure and animal is subject to sampling error, resulting in an estimate with multiple sources of sampling error and different levels of precision. From microhistological techniques with fecal samples, Mohammad et al. (1996) reported differences in botanical composition between diets collected from cows and steers. Mohammad et al. (1996) suggested that the difference between cow and steer diets might be attributed in part to past differences in grazing experience. Results from marker-based procedures for estimating forage intake and digestibility have been variable (Galyean et al., 1986). The greatest contribution of results from indirect methods may be identifying relative differences between treatments or forages. Caution must be used in making inferences from indirect methods.

At times it may be advantageous to harvest range or pasture forage and feed it in confinement to facilitate sampling; improve precision in estimating forage intake, digestibility, and particulate passage; or to control forage intake, diet, and(or) environmental factors. Villalobos et al. (1997b) fed harvested range and meadow forage to ruminally cannulated steers in confinement in conjunction with a winter supplement for gestating cows grazing winter range (Villalobos et al., 1997a). The grazing trial determined the effects of sup- plemental protein on forage intake and cow performance. The confinement experiment facilitated sampling procedures difficult on range and controlled the diet and level of intake so that the effects of the supplement on digesta kinetics could be determined. Sanson et al. (1990) used steers in confinement and cows grazing winter range to study the effects of protein supplements containing various levels of corn on intake, digestibility, and cow performance. Marston et al. (1995) studied the effects on protein and energy supplements before and after calving on the performance of grazing cows. In an associated confinement study, Marston and Lusby (1995) studied the effects of protein supplements, energy supplements, and lactational status of the cow on forage intake, forage digestibility, and energy intake. Pfister et al. (1998) used a combination of cows grazing rangeland and cows in confinement at the same location and time to study the effects of cow confinement and weather on consumption of needles from ponderosa pine.

\section{Applications to Production Systems}

\section{Systems Research}

Experiments with beef cows and calves grazing range or pasture have often studied portions or segments (Sanson et al., 1990; Short et al., 1996; Lamb et al., 1997) or multiple segments (Adams et al., 1989; Marston et al., 1995; Lardy et al., 1999) of an annual production cycle of the cow. This type of experiment may not always provide all of the information needed to incorporate it into year-long beef production systems. The impacts of applied treatments and responses during a segment of the production cycle on subsequent cow reproduction, calf weaning weight, or economic returns may not be known. Without information on a cow's annual production cycle, economic analysis of profitability and risk are not possible. For example, feeding a protein supplement during winter grazing may improve cow body condition during winter grazing, but if the effect of the supplement on subsequent performance such as pregnancy and weaning weight and production costs are not known, or if the effects are small, it might be ill advised to feed the supplement.

Systems research may logically follow more basic and segment research. In our judgment, there is a void in the literature and a need to incorporate findings from segment and mechanism research into production systems. Systems research generally requires considerable resources (Adams et al., 1994; Clark et al., 1997). Research conducted over full production cycles can tie up large numbers of cows and calves, large areas of range or pasture land, and all the required resources to care for cattle and forage resources over multiple years. Replication of systems in space may be particularly difficult. When systems experiments are difficult to replicate in space, use of years as replication can be particularly useful (Adams et al., 1989, 1994; Hart et al., 1991). As we demonstrated with data from our laboratory (Villalobos, 1993), the variance between animal may be much greater than the variance between pastures. Similarly, Conniffe 
(1976) concluded that using individual animals as the experimental unit under similar conditions will not seriously affect the conclusions drawn.

When the research objective is to compare production systems, replication in space can be difficult and impractical to implement. We compared six year-long feeding and grazing systems at the University of Nebraska with 240 cows (40 cows /system; Adams et al. 1994). The study used about $40 \%$ of the land, over 2,025 ha of rangeland and subirrigated meadow at the Gudmundsen Sandhills Laboratory. If each of the six systems had been replicated once, it would have required a minimum of 12 drylots for feeding hay, 6 pastures on subirrigated meadow, 12 pastures for summer grazing, 12 pastures for fall grazing, 2 pastures of range for winter grazing, and 2 meadow pastures for winter grazing. This would have required many kilometers of new fence; considerable development of watering systems; 24 bulls rather than 10 bulls; and more labor to move cows, to check cows, to feed cows, to calve the cows, and so on. The cited improvements and added labor alone would have taken resources far beyond all of the resources at the laboratory and the available funding. Additionally, the other $60 \%$ of the ranch resources would have had to be managed and no resources would have been available. Even if the replications could have been implemented, serious limitations would have remained, including testing of reproductive traits and developing homogeneous pasture for all the replications over the 2,025-ha landscape. Because it was impractical or impossible to implement replication in space, time was determined to be the most acceptable method of replication. Each group of 40 cows was considered the experimental unit, and the systems were replicated over 4 yr. Repeated measures on animals are correlated, thus introducing a correlated error structure. Methods are available (Littell et al., 1996) for appropriate analysis procedures for correlated errors. When such assumptions are made, a researcher must be cautious with interpretation and inferences. In other locations or production systems, replication in space can be much less demanding in terms of land area, water development, and so on (Coombs et al., 1983; Hitz and Russell, 1998) and thus more practical.

\section{Economic Evaluation of Beef/Forage Systems}

Economic evaluation of beef cattle systems can present some major challenges. Often the economist is brought in at or near the end of the biological study and asked to help evaluate the relative profitability or cost efficiency of the alternative systems/treatments. Unfortunately, some important data may not have been collected that would have made such an evaluation more accurate and meaningful. It is also helpful to the study design if all disciplines that are involved interact not only at the start, but also as the study moves along. It is important for the economist to understand the type and quality of data being developed.

For example, the relative amounts of labor used by alternative systems can be an important variable for economic analysis. Labor records must be maintained by those imple- menting the research as the research progresses or it will be difficult to know whether there truly are any differences between systems. It is important to understand how the labor records are kept and any "artificial" differences between treatments that may be due to research protocol or convenience that would not exist in an actual application.

We are keeping records on feeding and calving labor in an ongoing systems project. The labor records maintained by the research technicians have been very good, but we realized that the feeding labor contained relatively more travel time for one system than for another. The reason for the travel time differences was artificial in the sense that one set of cows was located 5 to $7 \mathrm{~km}$ farther from headquarters than the other group. In an actual ranch operating system, the location would likely be the same regardless of the system they were following. Without close involvement of the economist as the data were being collected, this difference would likely have gone unnoticed. Adjustment for travel distance not only affected labor but would also affect equipment and tractor costs.

It should be recognized that it is the relative differences in labor and costs between systems for relevant items that are important. A researcher must then interpret these relative differences into the scale (size) of analysis that is appropriate for the targeted population of ranches and farms. We have found it helpful to work with cooperators who keep good records to provide the scale and cost information that could be used in the economic analysis. Then, relative differences in labor and other costs (that may be affected by scale) can be used to achieve realistic estimates of costs and returns for the systems.

Another reason for keeping all disciplines involved centers around interpretation of the biological data, including formulation and testing of hypotheses. Traditional biological testing methodologies often set the probability of a type I error (rejecting $\mathrm{H}_{\mathrm{o}}$ when $\mathrm{H}_{\mathrm{o}}$ is true) equal to $5 \%$ (i.e., $\alpha=$ $.05)$. However, hypotheses that are rejected at the traditional $5 \%$ level for the biological analysis may not be rejected for economic analysis at some higher level such as 10 or $15 \%$. Part of the decision for setting the $\alpha$ value involves evaluating the relative costs of committing a type I or type II error (accepting $\mathrm{H}_{\mathrm{o}}$ when $\mathrm{H}_{\mathrm{o}}$ is false). In some cases, the consequences of a type II error may be more severe than those of a type I error, which the lower significance level $(\alpha)$ guards against. Furthermore, the relative costs of the two errors depend in part on the specification of the alternative hypothesis, $\mathrm{H}_{\mathrm{a}}$. Specification of $\mathrm{H}_{\mathrm{a}}$ should be based on prior research, preliminary data, or our conceptual models.

To demonstrate the concepts, suppose that $\mathrm{H}_{\mathrm{o}}$ posits that cattle pregnancy rates $(\mathbf{P R})$ between a control and treatment 1 are equal (i.e., $\mathrm{H}_{\mathrm{o}}: \mathrm{PR}_{\mathrm{c}}=\mathrm{PR}_{1}$ ). We could specify the alternative as $\mathrm{H}_{\mathrm{a}}$ : $\mathrm{PR}_{\mathrm{c}} \neq \mathrm{PR}_{1}$. Suppose $\mathrm{H}_{\mathrm{o}}$ is false but we do not reject it, so we have committed a type II error. If $\mathrm{H}_{\mathrm{a}}: \mathrm{PR}_{\mathrm{c}} \neq$ $\mathrm{PR}_{1}$ is true, then $\mathrm{H}_{\mathrm{o}}$ could be false because $\mathrm{PR}_{\mathrm{c}}>\mathrm{PR}_{1}$, or vice-versa. With this form of the alternative hypothesis $\left(\mathrm{PR}_{\mathrm{c}}\right.$ $\neq \mathrm{PR}_{1}$ ), we should conduct a two-tailed test for significance. The two-tailed test places a smaller rejection region in each tail of the distribution compared to the size of the rejection 
region in the single tail of the one-tailed test, assuming both tests use the same $\alpha$. The size of the area of acceptance (1$\alpha$ ) remains the same between the two types of tests but is located differently within the distribution.

The cost of the type II error to producers who change practices due to our results will be different depending on the correct alternative. If $\mathrm{H}_{\mathrm{a}}$ is true because $\mathrm{PR}_{\mathrm{c}}>\mathrm{PR}_{1}$ but we have not rejected $\mathrm{H}_{0}$ and a producer implements our treatment (for other reasons and the fact that we have said pregnancy rates are not different), the cost of the type II error is the reduced pregnancy rates. Pregnancy rate is one of the biological factors that strongly influences profitability (Melton, 1995). If $\mathrm{H}_{\mathrm{a}}$ is true because $\mathrm{PR}_{\mathrm{c}}<\mathrm{PR}_{1}$ and the producer changes, the producer's cattle pregnancy rates actually increase, so the cost of our error may actually be a gain. If we had specified the alternative hypothesis as $\mathrm{H}_{\mathrm{a}}: \mathrm{PR}_{1}>\mathrm{PR}_{\mathrm{c}}$, the rejection area for $\mathrm{H}_{0}$ would have all been concentrated in the upper tail of the test statistic and thus concentrate the rejection area (for example, the table " $t$ " value for rejection will be smaller compared to the two-tailed test and would require smaller, positive differences between the treatment and control for rejection of $\mathrm{H}_{\mathrm{o}}$ ) and increase the chance that we would have rejected $\mathrm{H}_{\mathrm{o}}$.

The cost of the type II error in this case is the loss of the potential gain in pregnancy rate (opportunity cost) if the change were made by the producer. If $\mathrm{H}_{\mathrm{o}}$ were in fact true and we reject it, we have created a type I error. The producer makes the change because of the perception that pregnancy rates will improve with our treatment. In fact, pregnancy rates do not change, so from that aspect the costs from making the change are any costs for making the change with no improvement in pregnancy rate. The cost of the type II error may be larger than the cost of the type I error because with the type II error the producer would forego making the change when in fact the change may have been profitable. We selected a small $\alpha$ to guard against the type I error, but that increased the chance of making the potentially more costly type II error. It may have been more efficacious to have chosen a larger $\alpha$ and thus reduce the probability of a type II error. Thus, the specification of the alternative hypothesis could influence the costs of a type I and type II, error and those relative costs may in turn influence our choice of $\alpha$.

An economist must, however, work with biologists to make sure that the differences at the lower level of significance (larger $\alpha$ ) are logical and likely to occur at that probability level in operating situations. The last thing we want to do is credit differences due to treatments or systems that are really due to uncontrollable errors in our research. If the biology results are determined not to be different, then the economic valuation should treat the systems or treatments the same by pooling the value for the nonsignificant result. For example, in one study the treatment $\times$ year interaction was insignificant for weaning weight, so we used a pooled weight over years and the same price for the calves from six different systems (Adams et al., 1994). Had that interaction been significant, we would have evaluated the systems with weaning weights matched to calf prices for each year, be- cause certain price situations may correspond with years in which a given treatment resulted in higher weaning weights while another system may have benefited in another year. In general, if the biological results are numerically different, yet not statistically significant, pooling the nonsignificant biological results (e.g., weaning weight) for the economic analysis seems logical.

Costs need to be compared for the appropriate products, especially in a system study. We could look just at cow costs, but that may give a biased picture unless the productivity per cow in the alternative systems is identical. It is much better to estimate cost per unit of calf weaned, which combines the cow costs with weaning weights and rates. If market timing and product (e.g., different market weight) are different between the alternatives, then we need to look at profitability to determine which treatments are different. For example, one study comparing early-, late-, and normally weaned calves found that the cow costs for the earlyweaning system were the least, but when the profitability of the systems was compared the early-weaning system was the least profitable (Story, 1998). If costs per unit of calf weaned were used instead of cow costs, the early-weaned calves had much higher cost because most cow costs have occurred by weaning and the weaned calves were lighter than their peers weaned later. Some of the higher cost for the early-weaned calves was offset by a higher price due to selling at a higher seasonal price and a lighter weight, but these did not overcome the difference in the cost per unit of weaned calf. In other situations, the higher seasonal price due to different market timing and price differential for lighter calves may result in lighter calves grossing about as much as those that are heavier (Clark and Adams, 1998). Costs must be estimated for the correct unit of output, and cost alone may be insufficient to properly rank the economic outcomes of the research.

\section{Implications}

Variation associated with time, location, animal, and error in grazing research can be high. Grazing studies generally require multiple years of study to address between-year variances. Vegetative measurements should be planned as a step in developing an experimental design and to aid in interpretation of data. Animals, pastures, or ranches have advantages and disadvantages as experimental units that are related to hypothesis, objectives, inference, resources, number of animals, and treatments. Hypothesis and interpretation of biological data may be different than for economic data.

\section{Literature Cited}

Adams, D. C., R. T. Clark, S. A. Coady, J. B. Lamb, and M. K. Nielsen. 1994. Extended grazing systems for improving economic returns from Nebraska sandhills cow/calf operations. J. Range Manage. 47:258-263.

Adams, D. C., T. C. Nelson, W. L. Reynolds, and B. W. Knapp. 1986. Winter grazing activity and forage intake of range cows in the Northern Great Plains. J. Anim. Sci. 62:1240-1246. 
Adams, D. C., and R. E. Short. 1987. The role of animal nutrition on productivity in a range environment. In: R. S. White and R. E. Short (ed.) Achieving Efficient Use of Rangeland Resources. pp 37-43. Montana Agric. Exp. Sta., Bozeman, MT.

Adams, D. C., R. E. Short, and B. W. Knapp. 1987. Body size and body condition effects on performance and behavior of grazing beef cows. Nutr. Rep. Int. 35:269-277.

Adams, D. C., R. B. Staigmiller, and B. W. Knapp. 1989. Beef production from native and seeded Northern Great Plains ranges. J. Range Manage. 42:243-247.

Adams, D. C., R. B. Staigmiller, B. W. Knapp, and J. B. Lamb. 1993. Native or seeded rangeland for cows with high or low milk production. J. Range Manage. 46:474-478.

Ahmed, J., C. D. Bonham, and W. A. Laycock. 1983. Comparison of techniques used for adjusting biomass estimates by double sampling. J. Range Manage. 36:217-221.

Anderson, D. M., and M. M. Kothmann. 1982. A two-step sampling technique for estimating standing crop of herbaceous vegetation. J. Range Manage. 35:675-677.

Anderson, D. M., and N. S. Urquhart. 1986. Using digital pedometers to monitor travel of cows grazing arid rangeland. Appl. Anim. Behav. Sci. 16:11-23.

Anderson, G. L., and J. D. Hansen. 1992. Evaluating hand-held radiometer derived vegetation indices for estimating above ground biomass. Geocarto Int. 1:71-78.

Arnold, G. W., and R. A. Maller. 1977. Effects of nutritional experience in early and adult life on the performance and dietary habits of sheep. Appl. Anim. Ethol. 3:5-26.

Brown, M. A., and S. S. Waller. 1986. The impact of experimental design on the application of grazing research results-an exposition. J. Range Manage. 39:197-200.

Brummer, J. E. 1994. Effect of carryover herbage on utilization of little bluestem. Ph.D. dissertation. Univ. of Nebraska, Lincoln.

Butts, W. T., M. Koeger, O. F. Pahnish, W. C. Burns, and E. J. Warick. 1971. Performance of two lines of Hereford cattle in two environments. J. Anim. Sci. 33:923-932.

Catchpole, W. R., and C. J. Wheeler. 1992. Estimating plant biomass: a review of techniques. Aust. J. Ecol. 17:121-131.

Clark, R. T., and D. C. Adams. 1998. Low input cow/calf systems. In: Proc. Managing for Profitability in the Beef Industry. Integrated Resource Management Conf., Nov. 5-6, Kearney, NE. pp $1-14$.

Clark, R. T., D. C. Adams, G. P. Lardy, and T. J. Klopfenstein. 1997. Matching calving date with forage nutrients: Production and economic impacts. In: Proc. Range Beef Cow Symp. XV, Rapid City, SD. pp 223-232.

Cochran, R. C., D. C. Adams, P. O. Currie, and B. W. Knapp. 1986. Cubed alfalfa hay or cottonseed meal-barley as supplements for beef cows grazing fall-winter range. J. Range Manage. 39:361364.

Cochran, W. G., and G. M. Cox. 1957. Experimental Designs. 2nd ed. John Wiley \& Sons, New York.

Colburn, D. J., G. H. Deutscher, M. K. Nielsen, and D. C. Adams. 1997. Effects of sire, dam traits, calf traits, and environment on dystocial and subsequent reproduction of two-year-old heifers. J. Anim. Sci. 75:1452-1460.

Conniffe, D. 1976. A comparison of between and within herd variance in grazing experiments. Ir. J. Agric. Res. 15:39-46.

Cook, C. W. 1966. Factors affecting utilization of mountain slopes by cattle. J. Range Manage. 19:200-204.

Cook, C. W., K. Taylor, and L. E. Harris. 1962. The effect of range condition on and intensity of grazing upon daily intake and nutritive value of the diet on desert ranges. J. Range Manage. 15:1-6.

Coombs, D. F., S. A. Phillips, J. L. Bartleson, K. L. Koonce, and D. C. Huffman. 1983. Pasture management systems for cow-calf production at two locations in northeast Louisiana. Louisiana Agric. Exp. Sta. Bull. No. 744. Baton Rouge, LA.

Cox, D. R. 1958. Planning of Experiments. John Wiley \& Sons, New York.

Cullan, A. P., P. E. Reece, and W. H. Schacht. 1999. Early-summer grazing effects on defoliation and tiller demography of prairie sandreed. J. Range Manage. 52:447-453.

Derner, J. D., R. L. Gillen, F. T. McCollum, and K. W. Tate. 1994. Little bluestem tiller defoliation patterns under continuous and rotational grazing. J. Range Manage. 47:220-225.

Downs, D. 1997. Diet composition of sandhills winter range and compensatory growth of yearling steers during summer grazing. M.S. thesis. Univ. of Nebraska, Lincoln.

Dwyer, D. D. 1961. Activities and grazing preferences of cows with calves in northern Osage county, Oklahoma. Oklahoma Agric. Exp. Sta. Bull. B-588, Stillwater, OK.

Frame, J. 1981. Herbage mass. In: J. Hodgson, R. D. Baker, A. Davies, A. S. Laidlaw, and J. D. Leaver (ed.) Sward Measurement Handbook. British Grassland Society, Hurley, Berkshire, U.K.

Galyean, M. L., L. J. Krysl, and R. E. Estell. 1986. Marker-based approaches for estimation of fecal output and digestibility in ruminants. In: Symp. Proc.: Feed Intake by Beef Cattle. pp 96-113. Agric. Exp. Sta. MP-121, Oklahoma State Univ., Stillwater.

Ganskap, D. and R. Cruz. 1999. Selective differences between naive and experienced cattle foraging among eight grasses. Appl. Anim. Behav. Sci. 62:293-303.

George, M. R., C. A. Raguse, W. J. Clawson, C. B. Wilson, R. L. Willoughby, N. K. Mcdougald, D. A. Duncan, and A. H. Murphy. 1988. Correlation of degree-days with annual herbage yields and livestock gains. J. Range Manage. 41:193-197.

Gillen, R. L., F. T. McCollum, and J. E. Brummer. 1990. Tiller defoliation patterns under short duration grazing in tallgrass prairie. J. Range Manage. 43:95-99.

Gillen, R. L., and K. W. Tate. 1993. The constituent differential method for determining live and dead herbage. J. Range Manage. 46:142-147.

Goebel, C. J., and C. W. Cook. 1960. Effect of range condition on plant vigor, production and nutritive value of forage. J. Range Manage. 13:307-313.

Hancock, R. H., G. H. Deutscher, M. K. Nielsen, and D. J. Colburn. 1994. Effects of Synovex $C^{\circledR}$ implants on growth rate, pelvic area, reproduction, and calving performance of replacement heifers. J. Anim. Sci. 72:292-299.

Hart, R. H. 1987. Economic analysis of stocking rates and grazing systems. In: Proc. Range Beef Cow Symp. X, Cheyenne,WY. pp 163-172.

Hart, R. H., M. J. Samuel, J. W. Waggoner, Jr., and M. A. Smith. 1991.Grazing systems in Wyoming-Impacts of grazing pressure and livestock distribution. Rangelands 13:12-16.

Heldt, J. S., R. J. Pruitt, C. P. Birkelo, P. S. Johnson, and Z. W. Wicks III. 1998. Evaluation of wheat middlings as a supplement for beef cows grazing native winter range with differing forage availabilities. J. Anim Sci. 76:378-387.

Herbel, C. H., and A. B. Nelson. 1966. Activities of Hereford and Santa Gertrudis cattle on a southern New Mexico range. J. Range Manage. 19:173-176.

Hitz, A. C., and J. R. Russell. 1998. Potential of stockpiled perennial forages in winter grazing systems for pregnant beef cows. J. Anim. Sci. 76:404-415.

Hodgson, J., D. A. Clark, and R. J. Mitchell. 1994. Foraging behavior in grazing animals and its impact on plant communities. In: G. C. Fahey, Jr., M. Collins, D. R. Mertins, and L. E. Moser (ed.) Forage Quality, Evaluation, and Utilization. pp 796-827. Am. 
Soc. Agron., Crop Sci. Soc. Am., and Soil Sci. Soc. Am., Madison, WI.

Hollingsworth-Jenkins, K. J., T. J. Klopfenstein, D. C. Adams, and J. B. Lamb. 1996. Ruminally degradable protein requirement of gestating beef cows grazing native winter sandhills range. J. Anim. Sci. 74:1343-1348.

Holscher, C. E., and E. J. Woolfolk. 1953. Forage utilization by cattle on Northern Great Plains ranges. USDA Circular No. 918, Washington, DC.

Houston, W. R., and R. R. Woodward. 1966. Effects of stocking rates on range vegetation and beef cattle production in the Northern Great Plains. USDA Tech. Bull. No. 1357, Washington, DC.

Huete, A. R., and R. G. Jackson. 1987. Suitability of spectral indices for evaluating vegetation characteristics on arid rangelands. Remote Sens. Environ. 23:213-232.

Hurtt, L. C. 1951. Managing Northern Great Plains cattle ranges to minimize effects of drought. USDA Circular No. 865, Washington, DC.

Judkins, M. B., J. D. Wallace, E. F. Parker, and J. D. Wright. 1985. Performance and phosphorus status of range cows with and without phosphorus supplementation. J. Range Manage. 38:139143.

Jung, H. G., and T. Sahlu. 1989. Influence of grazing pressure on forage quality and intake by sheep grazing smooth bromegrass. J. Anim Sci. 67:2089-2097.

Karn, J. F. 1997. Phosphorus supplementation of range cows in the Northern Great Plains. J. Range Manage. 50:2-9.

Karn, J. F., and D. C. Clanton. 1977. Potassium in range supplements. J. Anim Sci. 45:1426-1434.

Kartchner, R. J. 1980. Effects of protein and energy supplementation of cows grazing native winter range forage on intake and digestibility. J. Anim. Sci. 51:432-438.

Kartchner, R. J., J. R. Wight, J. L. Bishop, and R. A. Bellows. 1983. Beef and forage production on contour furrowed rangeland interseeded with alfalfa. J. Range Manage. 36:479-482.

Kennedy, P. 1992. A Guide to Econometrics. MIT Press, Cambridge, MA.

Kilcher, M. R. 1980. Influence of test period and sequence of years on results with perennial forage crops in a semiarid region. Can. J. Plant Sci. 60:1191-1201.

Laca, E. A., E. D. Unger, N. G. Seligman, and M. W. Demment. 1992. Effects of sward height and bulk density on bite dimensions of cattle. Grass Forage Sci. 47:91-102.

Lamb, J. B., D. C. Adams, T. J. Klopfenstein, W. W. Stroup, and G. P. Lardy. 1997. Range or meadow regrowth and weaning effects on 2-year-old cows. J. Range Manage. 50:16-19.

Lardy, G. P. 1997. Protein supplementation of calves and cows grazing sandhills range and subirrigated meadow. Ph.D. dissertation, Univ. of Nebraska, Lincoln.

Lardy, G. P., D. C. Adams, T. J. Klopfenstein, and R. T. Clark. 1999. First limiting nutrient for summer calving cows grazing autumn-winter range. J. Range Manage. 52:317-326.

Lathrop, W. J., D. D. Kress, K. M. Havstad, D. E. Dornbos, and E. L. Ayers. 1988. Grazing behavior of rangeland beef cows differing in milk production. Appl. Anim. Behav. Sci. 21:315-327.

Littell, R. C., G. A. Milliken, W. W. Stroup, and R. D. Wolfinger. 1996. SAS ${ }^{\circledR}$ system for mixed models. SAS Inst. Inc., Cary, NC.

Malechek, J. C., and B. M. Smith. 1976. Behavior of range cows in response to winter weather. J. Range Manage. 29:9-12.

Marston, T. T., and K. S. Lusby. 1995. Effects of energy or protein supplements and stage of production on intake and digestibility of hay by beef cows. J. Anim. Sci. 73:651-656.

Marston, T. T., K. S. Lusby, R. P. Wettemann, and H. T. Purvis. 1995. Effects of feeding energy or protein supplements before or after calving on performance of spring-calving cows grazing native range. J. Anim Sci. 73:657-664.

McIntyre, G. A. 1982. Statistical aspects of vegetation sampling. In: L. 't Mannetje (ed.) Measurement of Grassland Vegetation and Animal Production. Commonwealth Agric. Bureaux, Hurley, Berkshire, U.K.

Melton, B. 1995. Conception to consumption: Economics of genetic improvement. In: Proc. of Beef Improvement Federation, Sheridan, WY. p 40.

Mitchell, R. J., J. Hodgson, and D. A. Clark. 1991. The effect of varying leafy sward height and bulk density on the ingestive behaviour of young deer and sheep. Proc. N.Z. Soc. Anim. Prod. 51:159-165.

Mueggler, W. F. 1965. Cattle distribution on steep slopes. J. Range Manage. 18:255-257.

Mohammad, A. G., C. A. Ferrando, L. W. Murray, R. D. Piper, and J. D. Wallace. 1996. Season and sex influences on botanical composition of cattle diets in southern New Mexico. J. Range Manage. 49:204-208.

Morley, F. H. W. 1982. Animal production studies on grassland. In: L. 't Mannetje (ed.) Measurement of Grassland Vegetation and Animal Production. Bull. 52, Commonwealth Agric. Bureaux, Hurley, Berkshire, U.K

Nielsen, D. B. and M. H. Ralphs. 1988. Larkspur: Economic consideration. In: L. F. James, M. H. Ralphs, and D. B. Nielsen (ed.) The Ecology and Economic Impact of Poisonous Plants on Livestock Production. pp 119-130.Westview Press, Boulder, CO.

NRC. 1981. Effect of Environment on Nutrient Requirements of Domestic Animals. National Academy Press, Washington, DC.

NRC. 1996. Nutrient Requirements of Beef Cattle. 7th ed. National Academy Press, Washington, DC.

Oldenbroek, J. K., and A. A. M. Jansen. 1978/79. The effect of the grazing behavior of a breed on the performance of another breed, when they are mixed together. Z. Tierz. Zuechtungsbiol. 95:132139.

Osuji, P. O. 1974. The physiology of eating and the energy expenditure of the ruminant at pasture. J. Range Manage. 37:437-443.

Ostle, B., and R. W. Mensing. 1975. Statistics in Research. 3rd ed. The Iowa State University Press, Ames.

Perez-Castillo, E. J. 1998. Determination of biophysical variables using remote sensing techniques. Ph.D. dissertation. Univ. of Nebraska, Lincoln.

Powell, D. J., D. C. Clanton, and J. T. Nichols. 1982. Effect of range condition on the diet and performance of steers grazing native sandhills range in Nebraska. J. Range Manage. 35:96-99.

Pfister, J. A., K. E. Panter, and D. R. Gardner. 1998. Pine needle consumption by cattle during winter in South Dakota. J. Range Manage. 51:551-556.

Pfister, J. A., M. H. Ralphs, G. D. Manners, D. R. Gardner, K. W. Price, and L. F. James. 1997. Early season grazing by cattle of tall larkspur- (Delphinium spp.) infested rangeland. J. Range Manage. 50:391-398.

Prescott, M. L., K. M. Havstad, K. M. Olson-Rutz, E. L. Ayers, and M. K. Petersen. 1994. Grazing behavior of free-ranging beef cows to initial and prolonged exposure to fluctuating thermal environments. Appl. Anim. Behav. Sci. 39:103-113.

Ralphs, M. H. 1997. Persistence of aversions to eat larkspur in naive and native cattle. J. Range Manage. 50:367-370.

Rayburn, B. R., and S. B. Rayburn. 1998. A standardized plate meter for estimating pasture mass in on-farm research trials. Agron. J. 90:238-241.

Richards, M. W., J. C. Spitzer, and M. B. Warner. 1986. Effect of varying level of postpartum nutrition and body condition at calv- 
ing on subsequent reproductive performance in beef cattle. J. Anim. Sci. 62:300-306.

Roath, L. R., and W. C. Krueger. 1982. Cattle grazing and behavior on a forested range. J. Range Manage. 35:332-338.

Robel, R. J., J. N. Briggs, A. D. Dayton, and L. C. Hubert. 1970. Relationships between visual obstruction measurements and weight of grassland vegetation. J. Range Manage. 23:295-297.

Rook, A. J. 1999. Reply to letter to the editor. The use of groups or individuals in the design of grazing experiments. Appl. Anim. Behav. Sci. 61:357-358.

Sanson, D. W., D. C. Clanton, and I. G. Rush. 1990. Intake and digestion of low quality meadow hay by steers and performance of cows on native range when fed protein supplements containing various levels of corn. J. Anim. Sci. 68:595-603.

Scarnecchia, D. L. 1985. The animal-unit and animal-unitequivalent concepts in range sciences. J. Range Manage. 38:346349.

Sharrow, S. H. 1984. A simple disc meter for measurement of pastures heights and forage bulk. J. Range Manage. 37:94-95.

Short, R. E., E. E. Grings, M. D. MacNeil, R. K. Heitschmidt, M. R. Haferkamp, and D. C. Adams. 1996. Effects of time of weaning, supplement, and sire breed of calf during the fall grazing period on cow and calf performance. J. Anim. Sci. 74:1701-1710.

Smart, A. J., W. H. Schacht, J. F. Pedersen, D.J. Undersander, and L. E. Moser. 1998. Prediction of leaf:stem ratio in grasses using near infrared reflectance spectroscopy. J. Range Manage. 51:447-449.

Smoliak, S. 1986. Influence of climate conditions on production of Stipa-Bouteloua prairie over a 50-year period. J. Range Manage. 39:100-103.

Smoliak, S., and H. F. Peters. 1955. Climatic effects on foraging performance of beef cows on winter range. Can. J. Agric. Sci. 35:213-216

Spitzer, J. C., D. G. Morrison, R. P. Wettemann, and L. C. Faulkner. 1995. Reproductive responses and calf birth and weaning weights as affected by body condition at parturition and postpartum weight gain in primiparous beef cows. J. Anim. Sci. 73:1251-1257.

SRM. 1986. Range Research: Basic Problems and Techniques. C. W. Cook and J. Stubbendieck (ed.). Society for Range Management, Denver, CO.

Steel, R. G. D., and J. H. Torrie. 1980. Principles and Procedures of Statistics: A Biometrical Approach. 2nd ed. Mcgraw-Hill Publishing Co., New York.

Stoddart, L. A., A. D. Smith, and T. W. Box. 1975. Range Management. 3rd ed. McGraw-Hill Publishing Co., New York.

Story, Charles E., III. 1998. Effects of calf age at weaning on spring-calving cow and calf performance and production economics. M.S. thesis. Univ. of Nebraska, Lincoln.

Streeter, C. L., D. C. Clanton, and D. E. Hoehne. 1968. Influence of advance in season on nutritive value of forage consumed by cattle grazing western Nebraska native range. Agric. Exp. Sta. Res. Bull. 227, Univ. of Nebraska, Lincoln. pp 1-21.

Stricklin, W. R., and C. C. Kautz-Scanavy. 1983/84. The role of behavior in cattle production: A review of research. Appl. Anim. Ethol. 11:359-390.

Stricklin, W. R., L. L. Wilson, and H. B. Graves. 1976. Feeding behavior of Angus and Charolais-Angus cows during summer and winter. J. Anim. Sci. 43:721-732.

Thompson, W. R., J. C. Meiske, R. D. Goodrich, J. R. Rust, and F. M. Byers. 1983. Influence of body composition on energy requirements of beef cows during winter. J. Anim. Sci. 56:12411252.
Tilley, J. M. A., and R. H. Terry. 1963. A two stage technique for the in vitro digestion of forage crops. J. Brit. Grassl. Soc. 18:104111.

't Mannetje, L., and K. P. Haydock. 1963. The dry-weight-rank method for the botanical analysis of pasture. J. Br. Grassl. Soc. 18:268-275.

Villalobos, G. 1993. Integration of complementary forage with native range for efficient beef production in the sandhills of $\mathrm{Ne}$ braska. Ph.D. dissertation. Univ. of Nebraska, Lincoln.

Villalobos, G., D. C. Adams, T. J. Klopfenstein, J. T. Nichols, and J. B. Lamb. 1997a. Grass hay as a supplement for grazing cattle. I. Animal performance. J. Range Manage. 50:351-356.

Villalobos, G., T. J. Klopfenstein, D. C. Adams, D. Shain, and T. E. Long. 1997b. Grass hay as a supplement for grazing cattle. II. Ruminal digesta kinetics. J. Range Manage. 50:357-360.

Volesky, J. D., W. H. Schacht, and P. E. Reece. 1999. Leaf area index, visual obstruction, and standing crop relationships on Nebraska Sandhills rangeland. J. Range Manage. 52:494-499.

Wagnon, K. A. 1963. Behavior of beef cows on a California range. Calif. Agric. Ext. Serv. Bull. 799. Davis, CA.

Waller, S. S., L. E. Moser, and B. Anderson. 1986. A guide for planning and analyzing a year-round forage program. EC 86113-C. Univ. of Nebraska Coop. Ext., Lincoln.

Warren, J. T., and I. Mysterud. 1993. Extensive ranging by sheep released onto unfamiliar range. Appl. Anim. Behav. Sci. 38:6773.

Welles, J. M. and J. M. Norman. 1991. Instrument for indirect measurement of canopy architecture. Agron. J. 83:818-825.

Winder, J. A., D. A. Walker, and C. C. Bailey. 1996. Effect of breed on botanical composition of cattle diets on Chihuahuan desert range. J. Range Manage. 49:209-214.

\section{Notes}

1. Journal paper no. 12760 of the Agric. Res. Div., Univ. of Nebraska-Lincoln 68583-0704.

2. Correspondence: $461 \mathrm{~W}$. University Drive, North Platte, NE 69101 (phone: 308-532-3611, ext. 133; fax: 308-5323823; E-mail: dadams1@unl.edu). 
Table 1. Factors affecting experimental error in grazing studies

\begin{tabular}{|c|c|c|}
\hline Factor & Experimental variables affected & References \\
\hline \multirow[t]{3}{*}{ Breed of cow and calf } & $\begin{array}{l}\text { Milk production, weaning weight, nutrient require- } \\
\text { ments }\end{array}$ & Adams et al., 1993; NRC, 1996; Short et al., 1996 \\
\hline & Grazing behavior, daily travel & $\begin{array}{l}\text { Herbel and Nelson, 1966; Stricklin et al., 1976; Anderson and Urqu- } \\
\text { hart, 1986; Stricklin and Kautz-Scanavy, 1983/84; Lathrop et al., } 1988\end{array}$ \\
\hline & Diet selection & Winder et al., 1996 \\
\hline Body size & $\begin{array}{l}\text { Forage intake, grazing behavior, nutrient require- } \\
\text { ments }\end{array}$ & $\begin{array}{l}\text { Adams et al., 1987; } \\
\text { NRC, } 1996\end{array}$ \\
\hline Body condition & $\begin{array}{l}\text { Forage intake, grazing behavior, nutrient require- } \\
\text { ments, reproduction }\end{array}$ & $\begin{array}{l}\text { Adams et al., 1987; Thompson et al., 1983; } \\
\text { NRC, 1996; Spitzer et al., 1995; Richards et al., } 1986\end{array}$ \\
\hline Cow age & $\begin{array}{l}\text { Grazing behavior, forage intake, milk production, } \\
\text { nutrient requirements }\end{array}$ & $\begin{array}{l}\text { Adams et al. 1986; } \\
\text { NRC, } 1996\end{array}$ \\
\hline Gestation & Nutrient requirements & NRC, 1996 \\
\hline Days into lactation & Milk production, nutrient requirements & NRC, 1996 \\
\hline Birth date of calf & Weaning weight, milk production & Adams et al., 1987; NRC 1996 \\
\hline Sex of calf & Weaning weight & Adams et al., 1987; Adams et al., 1993 \\
\hline $\begin{array}{l}\text { Origin of animals, nutritio- } \\
\text { nal experience }\end{array}$ & $\begin{array}{l}\text { Birth weight, body weight gain, grazing preferences, } \\
\text { intake, animal distribution }\end{array}$ & $\begin{array}{l}\text { Butts et al., 1971; Arnold and Muller, 1977; Warren and Mysterud, } \\
\text { 1993; Ganskop and Cruz, } 1999\end{array}$ \\
\hline $\begin{array}{l}\text { Pasture topography and } \\
\text { water location }\end{array}$ & Cattle distribution, vegetation use, grazing behavior & $\begin{array}{l}\text { Mueggler, 1965; Roath and Krueger, 1982; } \\
\text { Cook, 1966; Holscher and Woolfolk, 1953; } \\
\text { Hart et al., 1991; Dwyer, } 1961\end{array}$ \\
\hline Soil type & Vegetation use & Holscher and Woolfolk, 1953 \\
\hline \multirow[t]{2}{*}{ Stocking rate } & Plant cover, herbage production, range condition & Houston and Woodward, 1966 \\
\hline & $\begin{array}{l}\text { Diet quality, forage digestibility, forage intake, body } \\
\text { weight gains }\end{array}$ & $\begin{array}{l}\text { Houston and Woodward, 1966; } \\
\text { Jung and Sahlu, 1989; Heldt et al., } 1998\end{array}$ \\
\hline Range condition & Weaning weight & Houston and Woodward, 1966 \\
\hline Days in lactation & Milk production, nutrient requirements & NRC, 1996 \\
\hline Calving date & Weaning weight, milk production & NRC, 1996; Adams et al. 1989 \\
\hline Sex of calf & Weaning weight & Adams et al., 1989; Adams et al. 1993 \\
\hline
\end{tabular}


Year and season

Precipitation

Precipitation pattern

Ambient temperature

Wind velocity

Snow cover
Forage intake, diet crude protein, crude protein of the standing herbage

Herbage production, nutrient content or diet

Herbage production

Diet composition

Herbage production

Forage intake, forage digestibility, grazing behavior, nutrient requirements, diet selection

Grazing behavior, forage intake, forage digestibility, animal travel and movements, nutrient requirements

Grazing behavior, diet selection, travel and movement, forage intake
Cook et al., 1962; Goebel and Cook, 1960;

Powell et al., 1982

Kartchner, 1983; Streeter et al., 1968; Adams and Short, 1987

Holscher and Woolfolk, 1953; Kartchner et al., 1983; Stoddart et al., 1975; Kilcher, 1980; Smoliak, 1986; George et al., 1988

Short et al., 1996

Hart, 1987; Smoliak, 1986

NRC, 1981; NRC, 1996; Kartchner, 1980; Adams et al., 1986;Adams et al., 1987, Pfister et al., 1998; Smoliak and Peters, 1955; Malachek and Smith, 1976; Dwyer, 1961; George et al., 1988; Prescott et al., 1994

Dwyer, 1961;

Adams et al., 1986;

NRC, 1981; NRC, 1996

Adams et al., 1986,

Pfister et al., 1998;

Adams et al., unpublished data 
Table 2. Mean squares and degrees of freedom (df) for pasture and year from two trials with cows grazing on winter range

Trial 1. Downs (1997)

\begin{tabular}{lcccccccc} 
Trait & Pasture(TMT) & df & Yr & df & TMT x yr & df & Yr $\times$ pasture (TMT) & df \\
\hline Diet IVOMD & 7.61 & 14 & 77.0 & 1 & 9.75 & 6 & 7.48 \\
Diet Crude protein & 1.69 & 14 & 131.7 & 1 & 0.28 & 6 & 0.76
\end{tabular}

$\underline{\text { Trial 2. Villalobos (1993) }}$

\begin{tabular}{lccccccc} 
& Pasture & & & & \multicolumn{2}{c}{ Animal (pasture $\times$ yr $\times$} \\
Trait & $($ TMT $\times$ yr) & df & Yr & df & TMT $\times$ yr & df & df \\
\hline Change in cow body condition & 0.387 & 8 & 0.105 & 1 & 0.546 & 3 & 0.420 \\
Change in cow body weight & 736 & 8 & 35,400 & 1 & 3,190 & 3 & 259 \\
\hline
\end{tabular}


Table 3. Advantages and disadvantages of using individual animals, pastures, or ranches (herds) as experimental units in supplement studies on rangeland

\begin{tabular}{|c|c|c|}
\hline Experimental unit & Advantage & Disadvantage \\
\hline Individual animal & $\begin{array}{l}\text { Potential for more replications } \\
\text { Removes between-pasture variation } \\
\text { Reduces land and animal resources required to conduct } \\
\text { the research } \\
\text { Reduces between-animal variation in consumption of } \\
\text { supplements } \\
\text { Highly effective for studying mechanisms such as forage } \\
\text { intake, passage rate, or diet selection }\end{array}$ & $\begin{array}{l}\text { Inference is more limited than with multiple pastures } \\
\text { Pasture } \times \text { treatment interactions cannot be tested } \\
\text { Handling of animals is artificial and may affect herd behavior } \\
\text { Labor and equipment for feeding individual animals are consid- } \\
\text { erable } \\
\text { Disregards social facilitation and competition among animals } \\
\text { People may be more exposed to harsh weather }\end{array}$ \\
\hline Pasture & $\begin{array}{l}\text { Group feeding is similar to ranch production, competition } \\
\text { between animals is maintained } \\
\text { Labor and equipment requirements are lower than for } \\
\text { feeding individual animals } \\
\text { Spatial inference is greater than with single pastures } \\
\text { Large numbers of animals can be accommodated } \\
\text { Pasture } \times \text { treatment interactions can be tested }\end{array}$ & $\begin{array}{l}\text { Pastures are more difficult to replicate animals, usually results } \\
\text { in fewer replications than when animals are fed individually } \\
\text { As the number of treatments and(or) pastures increases, it is } \\
\text { likely to be more difficult to maintain similar stocking } \\
\text { rates between pastures } \\
\text { Fencing and water development will generally be greater for } \\
\text { multiple pastures than for one common pasture }\end{array}$ \\
\hline Ranch or herd & $\begin{array}{l}\text { If the intended inference is to ranches, then ranch replica- } \\
\text { tion can be particularly useful } \\
\text { Animal and pasture interactions are on a ranch scale } \\
\text { Potential for producer education is high }\end{array}$ & $\begin{array}{l}\text { Differences in weather and management are probable } \\
\text { Differences in forage and cattle genetics will occur } \\
\text { Replication and(or) finding ranches to cooperate may be a } \\
\text { challenge } \\
\text { The kinds and amount of data that can be collected will likely be } \\
\text { less than with individual animals or pastures as experimental } \\
\text { units } \\
\text { A collaborating ranch has risk of lower productivity or more } \\
\text { costly production because of research protocol }\end{array}$ \\
\hline
\end{tabular}

